\title{
Film dan Identitas Nasional Korea Selatan: Studi Komparasi pada Film My Little Hero dan Secretly Greatly
}

\author{
Amirah Anis Thalib \\ Magister Kajian Sastra dan Budaya \\ Universitas Airlangga
}

\begin{abstract}
Abstrak
Fabrikasi film tidak semata-mata ditujukan untuk menghibur penonton namun juga untuk mempengaruhi penonton melalui gagasan sang kreator yang salah satunya adalah gagasan mengenai identitas nsional. Penulis akan memaparkan bagaimana identitas nasional dihadirkan dalam dua film produksi Korea Selatan pada tahun 2013 yaitu A Wonderful Life dan Secretly Greatly. Melalui analisis yang dilakukan terhadap tiap karakter utama di kedua film, dapat disimpulkan bahwa terdapat kegalauan atas konsep identitas nasional Korea Selatan.
\end{abstract}

Kata kunci: film, identitas nasional, Korea Selatan

\section{Abstract}

Fabrication of film is not solely intended to entertain the audience but also to influence them through the film maker's ideas, one of them is national identity. The author will explain how national identity is presented in two South Korean films in 2013, they are A Wonderful Life and Secretly Greatly. Through analysis of each of the main characters in the two films, it can be concluded that there are confusions over the concept of South Korean's national identity.

Keywords: film, national identity, South Korea 


\section{PENDAHULUAN}

Praktik menonton filmsejak awal kemunculannya masih bertahan hingga sekarang. Cara menikmati filmmengalami perkembangan, mulai dari pergerseran dari menikmati film di gedung bioskop beralih ke memutar rekaman video yang bisa dilakukan di rumah. Bahkan di era internet ini menikmati film dapat dilakukan dimanapun dengan menggunakan teknologi smart phone. Terlepas dari hal itu, sinema selalu dapat menjadi tren budaya populer, sebagai contoh film $5 \mathrm{~cm}$, film produksi Indonesia yang pada tahun 2012 lalu memunculkan tren naik gunung terutama Gunung Semeru di kalangan anak muda. Tidak hanya sebagai hiburan, film juga dapat dimanfaatkan sebagai alat untuk menghegemoni penonton. Layaknya yang dilakukan penguasa terhadap rakyatnya. Bukan hal baru bahwa banyak penguasa - negara - mengatur ketentuan dan pengawasan dalam berbagai hal termasuk film. Hal ini dilakukan tentu untuk kepentingan politik penguasa yang menjabat. Salah satu negara yang terlibat dalam industri film adalah Korea Selatan.

Korea Selatan berhasil menarik perhatian melalui hallyu atau budaya nya yang disebarkan ke seluruh dunia. Diantara berbagai budaya, $k$ pop atau budaya populer Korea Selatan merupakan yang paling banyak mendapat perhatian melalui produk musik, drama, juga film. (Connor, 2009). Dalam tulisan ini akan dibahas relasi antara film dan identitas nasional suatu negara. Film yang akan dianalis adalah dua film berjudul My Little Hero dan Secretly Greatly kedua film ini mengangkat isu identitas di dalamnya. Analisis akan dilakukan dengan menggunakan metode komparasi.

Film MyLittle Hero merupakan filmbergenre drama musikal karya sutradara Kim Sung-Hoon yang rilis pada 10 Januari 2013. Film ini meraih penghargaan di PaekSang Arts Award pada Mei 2013 dengan kategori Best New Actor yang di raih oleh Ji Dae-Han sebagai pemeran YoungKwang. Filminiberkisah tentang pengarah musik bernama Yoo Il-Han (diperankan oleh Kim RaeWon) yang dulunya cukup diperhitungkan sampai akhirnya mengalami kerugian finansial. Kini dia hanya mengarahkan musik untuk anak-anak. Dia mencoba peruntungan dengan bergabung dalam sebuah kompetisi musik diTV. Kompetisi dengan pendanaan besar ini bertujuan menghasilkan seorang penyanyi yang akan menampilkan musikalisasi Raja Jungjo dari dinasti Joseon di panggung Broadway. Dalamkompetisi ini setiap pengarah musik bertugas memilih satu anak untuk dibimbing. Dia memilih anak laki-laki bernama Young-Kwan atau Glory yanng merupakan keturunan Korea-Filipina. Masalah mulai muncul ketika dia merasa anak yang dia pilih tidak memilikikemampuan untuk menampilkan apapun.

Film Secreatly Greatly disutradarai oleh Jang Cheol-Soo ini bergenre action, komedi, dan drama. Film yang rilis pada 5 Juni 2013 ini telah meraih beberapa penghargaan di Daejong Film Awards pada November 2013 dengan kategori Best New Actor yang diraih Kim Soo-Hyun, serta di PaekSang Arts Award pada Mei 2014 untuk kategori Best New Actor dan Most Popular Actor yang diraih Kim Soo-Hyun. Secretly Greatly berkisah tentang Won Ryu-Hwan (diperankan oleh Kim Soo-Hyun), yang ditugaskan menjadi mata-mata di Korea Selatan dengan misi utama reunifikasi negara. Selama menjadi mata-mata di Korea Selatan, dia ditempatkan di sebuah desa dan tidak mendapat insentif apapun dari negaranya. Dia juga diharuskan menyamarkan menjadi seorang yang mengalami keterbelakangan mental bernama Bang Dong-Gu. Setelah dua tahun penyamaran dan mengamatipenduduk desa di Korea Selatan, datang mata-mata lain 
dari Korea Utara, yaitu Rhee Hae-Rang yang menyamar menjadi musisi bernama Kim Min$\mathrm{Su}$ yang disusul oleh Rhee Hae-Jin yang menyamar menjadi siswa sekolah menengah. Selama penyamaran, mereka menunggu misi yang akan ditugaskan hingga suatu ketika terjadi perubahan politik di Korea Utara yang disusul dengan perintah bagi seluruh mata-mata yang ada di Korea Selatan untuk bunuh diri

Berdasarkan pemaparan yang telah dikemukakan sebelumnya pada bagian latar belakang, maka rumusan masalah yang akan dikaji pada bagian-bagian selanjutnya adalah,

'Bagaimana film $A$ Wonderfu Life danSecretly Greatly menghadirkan konsep identitas nasional?"

\section{KAJIAN PUSTAKA}

\section{Sinema Nasional Korea Selatan}

Fenomena bangkitnya industri film Korea Selatan dijelaskan oleh Sung Kyung Kim dalam tulisannya 'Renaissance of Korean National Cinema" as a Terrain of Negotiation and Contention between Global and the Local: Analysing two Korean Blockbusters, Shiri (1999) and JSA (2000). Menurutnya ada beberapa hal yang memicu fenomena ini, pertama sentimen kebangsaan diantara warga negara setelah krisis finansial pada 1997 yang menyebabkan bangkrutnya beberapa konglomerat. Krisis finansial ini berpengaruh besar terhadap perubahan yang terjadi pada kehidupan warga Korea Selatan yang dalam prosesnya memunculkan gerakangerakan pemersatu Korea yang salah satunya adalah gerakan pemboikotan film Hollywood dan kampanye menonton film Korea oleh para filmmaker (Sung).

Kedua, industrialisasi dan penataan ulang terhadap industri film juga merupakan faktor pengantar femonena bangkitnya perfilman Korea
Selatan. Sebelumnya, perfilman Korea Selatan dibatasi oleh beberapa sensor yang ditetapkan oleh rezim pemerintah otoriter, terutama rezim Park Jung-Hee (1963-1979) dan rezim Chun Do-Hwan (1980-1988). Pada kedua rezim ini, film Korea apapun yang mengangkat tema politik dan menunjukkan situasi sosial yang brutal dilarang untuk diproduksi dan diputar (Ibid). Setelah terpilihnya presiden Kim Young-Sam (1993-1997), terjadi banyak perubahan di negara ini baik itu sosial, politik, ekonomi, dan budaya. Sejak pergeseran ini industri film Korea Selatan terlahir kembali. Lepasnya sensor yang ketat terhadap film membuat para filmmaker lebih leluasa dalam menyuarakanisu-isu tertentu. Bahkan beredar anekdot bahwa Presiden Kim meningkatkan dukungannya pada industri media dan budaya karena terispirasi dari keuntungan film Jurassic Park yang menyamai ekspor 1.5 juta mobil Hyundai.(Vick, 2009:37).

Perubahan lain yang terjadi terkait dengan dukungan terhadap perfilman Korea selatan muncul dariberbagaikalangan seperti penanaman modal dan usaha produksi film domestik pada pertengahan 1990-an yang dilakukan oleh konglomerat-konglomerat finansial. Hal ini tentu saja mengindikasikan perubahan persepsi terhadap sinema dari yang semula hanya dianggap kesenian marjinal menjadi industri yang menguntungkan. Selain pendanaan yang stabil dari investor, para pemuda Korea Selatan turut berperan dalam pergerakan demokratis guna mengembangkan perfilman negara dengan membentuk ulang industrimelalui kebijakan filmyang lebih progresif dan liberal serta pembentukan 'Korean Film Council'. Dukungan dari pemerintah juga terus mengalir. Pada rezim selanjutnya, KimDae-Jung (1998-2002), beberapa kebijakan terkait promosi film diluncurkan seperti 'Dana Promosi Film', dan 'Dana Promosi Kebudayaan' dan mempro- 
mosikan investasi pribadi industri perfilman melalui sisten insentif pajak. (Kim)

Melalui perjuangan dan proses yang panjang, sinema Korea Selatan kini bisa dibilang menjadi raja di negaranya dan di Asia, menjadi rival sinema Hollyywood yang sudah lama merajai industri film di dunia. Menariknya, sinema Korea Selatan dikenal kental dengan unsur-unsur khas sepertibintangnyayang merupakan keturunan asli Korea, penggunaan bahasa nasional Korea, serta pemunculan nilai-nilai serta warisan budaya nasional yang biasa dipraktikkan oleh masyarakat. Dalam Kajian budaya, hal-hal tersebut merupakan penanda identitas.

Identitas merupakan suatu esensi yang dapat dimaknai melalui tanda-tanda selera, kepercayaan, sikap, dan gaya hidup. Identitas dianggap bersifat personal sekaligus sosial dan menandai bahwa kita sama atau berbeda dengan orang lain. Identitas bukanlah sesuatu yang serta merta kita miliki, ia merupakan konstruksi diskursif yang berubah maknanya menurut ruang, waktu, dan pemakaian (Barker, 2000: 174-175).

Dalam hal ini, konteks identitas yang dikonstruksi melalui film sudah bukan lagi bersifat personal atau sosial, tapi sudah bersifat nasional. Film yang merupakan produk yang banyak dikonsumsi sebagai seni maupun hiburan oleh masyarakat menjadi sarana penyebar nilainilai ke-Korea Selatan-an.

\section{Sinema dan Identitas Nasional}

Dalam beberapa usaha untuk memahami hubungan antara film dan kebudayaan banyak ditemukan asumsi bahwa terdapat relasi bersifat refleksionis yang melihat film sebagai sebuah refleksi dari kepercayaan-kepercayaan dan nilainilai dominan dari suatu kebudayaan (Griffith dalam Turner, 1988: 152). Kemudian muncul pandangan lain dalam peletakan hubungan antara film dan masyarakat dalam kategori yang lebih luas dari hubungan representasi dari apapun (foto, lukisan, novel, film) terhadap kebudayaan mereka. Film tidak merefleksikan atau bahkan merekam kenyataan, layaknya medium representasi lainnya ia mengkonstruksi dan merepresentasi gambar-gambar dari kenyataan melalui kode-kode, ketentuan-ketentuan, mitos-mitos, dan ideologi-ideologi dari kebudayaan yang bersangkutan maupun dengan praktik-praktik penandaan medium(Ibid).

Pelbagai kode, konvensi, mitos, serta ideologi yang ditampilkan dalam film dapat menunjukkan apapun yang diinginkan oleh filmmakers, termasuk menunjukkan identitas nasional. Identitas nasional merupakan sebentuk identifikasi yang diekspresikan negara-bangsa melaui simbolsimbol dan diskursus-diskursus. Narasikebangsaan dapat dipahami sebagai komunitas politis yang dibayangkan sebagai sesuatu yang bersifat terbatas secara inheren sekaligus berkedaulatan (Anderson, 2001: 8). Bangsa terbayang karena anggotanya tidak akan mengenal sebagian besar anggota lain, tapi dalam benak tiap anggota hidup bayangan tentang kebersamaan mereka (Ibid).

Sebagai pihak yang berkuasa atas bangsa, tentunya negara memiliki kepentingan untuk mengatur hajat hidup warganya, termasuk menanamkan ideologi kebangsaan yang dapat dilakukan dengan berbagai hal, seperti mengkonstruksi identitas nasional. Kuasa akan menjadi pangkal dari perintah apapun di masyarakat. Semakin absolut asal-muasalnya, makan semakin lengkap kuasanya. (Laclau dan Zac, 1994:17) Jika seorang individu atau sebuah kelompok mempunyai kekuasaan absolut dalam masyarakat, maka kelompok lain tidak dapat memiliki identitas lain sebagai pengaruh yang diperoleh dari kuasa tersebut, akibatnya, mereka juga akan menjadi bagian dari identitas kelompok dominan. Lebih lanjut, mereka menjelaskan bahwa identitas termediasi melaluimekanisme identifikasi (Ibid). 
Menurut Barker $(2004,92)$, Identifikasi melibatkan proses pendeskripsian, penamaan, dan pengklasifikasian.

\section{PEMBAHASAN}

\section{Identitas Nasional dalam Film My Little Hero dan Secretly Greatly}

Dalam bagian ini, bentuk-bentuk identitas nasional yang ada dalam film My Little Hero dan Secretly Greatly dijabarkan dengan mengkomparasi karakter Young-Kwan dalam film My Little Hero dan Won Ryu-Hwan dalam film Secretly Greatly karena dalam kedua film itu kedua karakter merupakan pemeran kunci dan mengalami krisis yang berkaitan dengan identitas. Analisis yang sifatnya naratif diperlukan guna mengetahui komponen yang terkandung, nilainila-, cita-cita, serta ideologi dalam media dan bentuk kultural apapun (Stokes, 2003: 72). Sumber data dari tulisan ini adalah film My Little Hero dan Secretly Greatly yang telah dilengkapi teks terjemahan berbahasan Indonesia.

\section{1. Penokohan Young-Kwan dalam Film My Little Hero}

Penerimaan Masyarakat terhadapYoungKwan yang Berdarah Campuran

Umumnya, film-film Korea Selatan dibintangi oleh aktor dan aktris keturunan Korea murni. Namun di film My Little Hero, salah satu tokoh kunci, yaitu Young-Kwan ditampilkan sebagai sosok berdarah campuran Korea-Filipina. Ji Dae-Han, pemeran tokoh ini juga berdarah campuran Korea- Sri Lanka. Ciri-ciri fisik yang ada pada tokoh Young-Kwan cukup berbeda dengan orang Korea pada umumnya. YoungKwan bermata lebar dan berkulit kecoklatan.

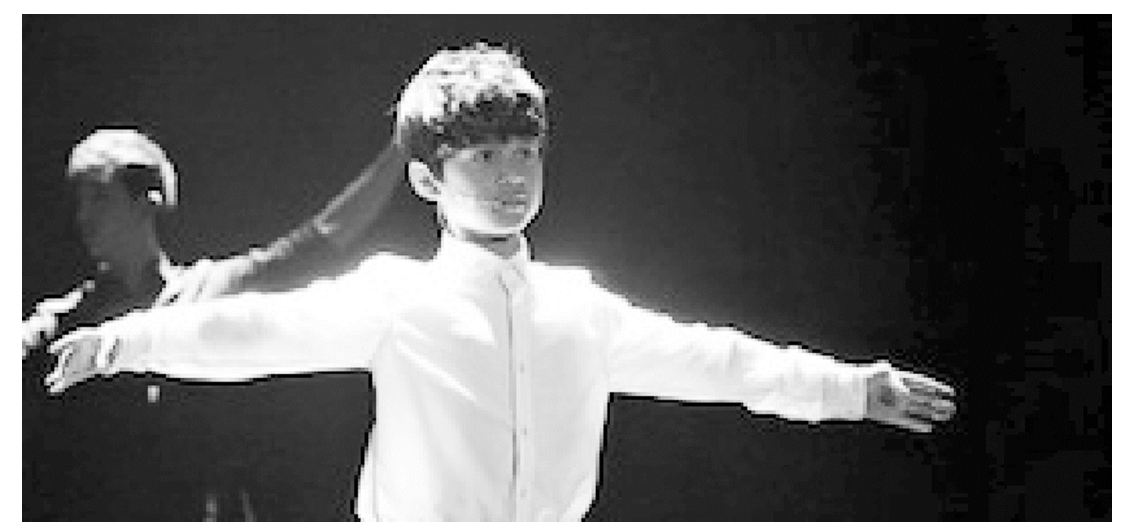

Young-Kwan atau Glory

Kenyataan bahwa dia tidak murni Korea mendatangkan kesulitan pada hidupnya. Dalam film ini Young-Kwan atau Glory terpilih untuk tampildalam acara audisi untuk drama musikal Raja Joseon. Namun muncul resistensi dari beberapa pihak atas terpilihya Young-Kwan

$\mathrm{Bu}$, tidakkah seharusnya orang Korea yang memerankan raja kita?

(My Little Hero, 00:07:03)

Penggalan dialog diatas menegaskan ketidaksetujuan dari orang yang murni Korea terkait dengan peran yang akan dilakoninya. Namun Young-Kwan tidak terlalu memikirkan hal ini, dia membuktikannya dengan menyemangati Sung-Joon, teman satu sekolahnya yang juga berdarah campuran.

Young-Kwan: Bagaimana dengan sepakbola? Bukankah kau mau jadi bintang?

Sung-Joon : Tidak di Korea, tidak untuk bocah kulit hitam.Orang-orang macam kita harus tahu diri dalam bermimpi. 
Young-Kwan: Orang macam kita?

Sung-Joon : Lupakan.

(My Little Hero, 00:21:21)

Teks diatas menegaskan wacana bahwa tidak ada ruang bagi etnis selain Korea murni meskipun kewarganegaraan mereka adalah Korea. Selanjutnya pernyataan dalam film yang dilontarkan oleh penata musik yang akan membina YoungKwan juga menegaskan hal ini.

Yoo Il-Han : Ini tidak beres, siapa yang mau memilihnya menjadi orang Korea?

(My Little Hero, 00:27:26)

Sung-Hee : Kalau warna kulit jadi masalah, dia takkan berada di sini.

Yoo Il-Han : Bagaimana mungkin orang-orang memilih orang Malaysia untuk jadi raja Korea?

Sung-Hee : Dia dari Filipina, kan?

Yoo Il-Han : Sama saja.

(My Little Hero, 00:28:59)

Pernyataan-pernyataan diatas dilontarkan Yoo Il-Han setelah bertemu Young-Kwan secara fisik. Padahal sebelumnya dia sendiriyang memilih Young-Kwan karena kualitas suaranya. Namun di sisi lain, Yoo Il-Han dan beberapa orang bersikeras bahwa pemeran Raja Joseon haruslah orang Korea murni. Keteguhan pendapat Yoo Il-Han di sisi lain, dilandasi oleh kekuatirannya atas perkembangan karir pribadinya karena kontes ini merupakan jalan penting demi kemajuan karirnya. Dia takut Young-Kwan malah akan menghambat jalannya.

Akan tetapi dalam film My Little Hero tidak semua orang Korea asli mendiskriminasi YoungKwan.

Soo-Hee

:Ya, warna kulitnya memang berbeda tapi dia lahir dan besar di sini, dan dia adalah warga negara Korea, jadi siapa bilang dia tak boleh memerankan raja kita? Apakah aku salah?

(My Little Hero, 00:46:51)

Soo-Hee : Mari kita perjuangkan ke stasiun TV. Korea cukup liberal untuk menerima keluarga multibudaya...

Ibu Young-Kwan : Kenapa kami butuh penerimaan?

Soo-Hee : : Maaf?

Ibu Young-Kwan : Apakah kami sebegitu menyedihkan? Kau merasa kasihan dengan kami? Orang-orang macam kalian adalah yang paling buruk, memberi kami harapan palsu. Seperti ayahnya Glory, dan sutradara Yu.

(My Little Hero, 01:36:18)

Penggalan dialog-dialog diatas tampaknya ingin menumbangkan wacana fanatisme akan darah murni yang tumbuh pada masyarakat Korea Selatan dengan memunculkan narasi dalam film tentang ke liberal-an Korea Selatan yang menandai bahwa negara ini siap dengan adanya multikulturalisme. Meskipun memang tidak dapat dipungkiri bahwa terjadi pro dan kontra terhadap multikulturalisme dalam konteks masyarakat Korea Selatan di luar film ini. Seperti yang terjadi pada saat terpilihnya seorang kelahiran Filipina sebagai sebagai anggota legislatif,

"...some South Koreans expressed discomfort about Philippines-born Jasmine Lee being elected the first non-ethnic Korean assemblyman in the 2012 Congressional Election.21 Although Lee is a naturalized citizen 
(citizenship granted by the government after the person fufills specific immigration requirements) of South Korea, she is still viewed as an outsider as she is not ethnically Korean." (New York Times, dalam Seow: 2013)

Disisi lain sebagian masyarakat Korea Selatan, menurut Kang Won-Taek yang telah melakukan survey atas identitas nasional Korea Selatan dan pemahaman kebangsaan Korea (dalam Lee, 2009: 4-5) menunjukkan bahwa kefanatikan akan homogenitas etnis akan berubah,

"We have lived for a long time within the myth of the homogeneous race. Such a myth of racial homogeneity, of the Korean people as descendants of the same ancestor has come under challenge as the ethnic composition of Korean society has been transformed. As more and more foreign workers come to reside in South Korea, and more Korean citizens marry foreigners and have "mixed-blood" offspring, the identity of the South Korean people, will continue to undergo change."

Ayah yang menjadikan Young-Kwan seorang Korea

Young-Kwan terlahir dari Ibu Filipina dan ayah yang murni Korea. Dalam film dikisahkan bahwa ayah Young-Kwan meninggalkannya dan ibunya. Bagi Young-Kwan, ayahnyalah yang menjadikannya seorang Korea.

"Tapikau orang Korea meski tak punya ayah."

"Tanpa ayahku, aku bukan orang Korea."

"Tentu tidak benar."
“Apapun itu, kau adalah orang Korea. Tak perlu pulang ke Filipina karena... ayahmu takkan mengizinkanmu. Benar, kan?"

(My Little Hero, 01:25:42)

Meski telah disemangati oleh banyak orang baik itu keluarga, kawan, maupun tim produksi di stasiun TV, Young-Kwan tetap merasa inferior atas statusnya sebagai orang Korea. Dia dapat membesarkan hati temannya yang juga berdarah campuran, namun disisi lain terdapat pergolakan dalam dirinya untuk memiliki penanda bahwa dia adalah orang Korea melalui kehadiran sang ayah.

\section{2. Penokohan Won Ryu-Hwan dalam Film}

\section{Secretly Greatly}

\section{Penerimaan Masyarakat terhadap Won Ryu-Hwan sebagai Etnis Korea Murni}

Dalam film Secretly Greatly, Won Ryu-Han ditampilkan sebagai seorang yang murni berdarah Korea. Dengan ciri-ciri fisik layaknya orang Korea kebanyakan, yaitu berambut hitam lurus, bermata sipit, dan berkulit putih kekuningan. Dalam film dia bertugas untuk menjalankan misi sebagai pasukan elite rahasia 5446 untuk menjadi mata-mata di Korea Selatan dengan misi utama reunifikasi dua negara. Pemunculan narasi reunifikasi negara erat kaitannya dengan konteks sejarah konflik antara Korea Selatan dan Korea Utara yang sampai sekarang masih berperang. 


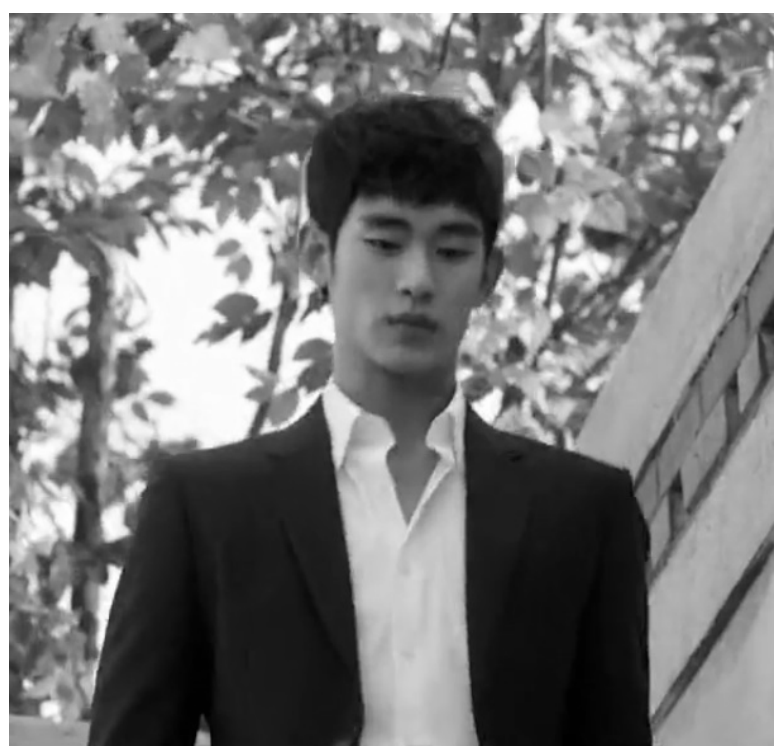

\section{Penampakan secara fisik Won Ryu-Hwan yang merupakan etnis Korea}

Dua tahun setelah pengugasan itu, di Seoul, Korea Utara, Won Ryu-Hwan hidup sebagai pemuda yang mengalami keterbelakangan mental bernama Bang Dong-Gu yang tinggal di sebuah desa. Selama tinggal di desa, dia bekerja pada Jeon Soon-Im, wanita berusia 58 tahun yang memiliki usaha toko kelontong. Setiap hari tugasnya menjaga toko, menyapu, dan mengantarkan barang pada pembeli, sebagai upahnya Bang Dong-Gu atau Won Ryu-Hwan diijinkan untuk menempati kamar di lantai dua, mendapat upah kerja setiap bulannya, serta makan dari majikannya. Dari toko kelontong itu dia bisa mengamati tindakan setiap warga desa. Sosok Bang Dong-Gu yang dikenal dan disukai banyak warga desa tidak hanya karena perbedaan perilakunya yang tidak sama dengan kebanyakan orang, tapi juga karena dia dikenal ramah, suka menolong, dan akrab dengan warga desa.

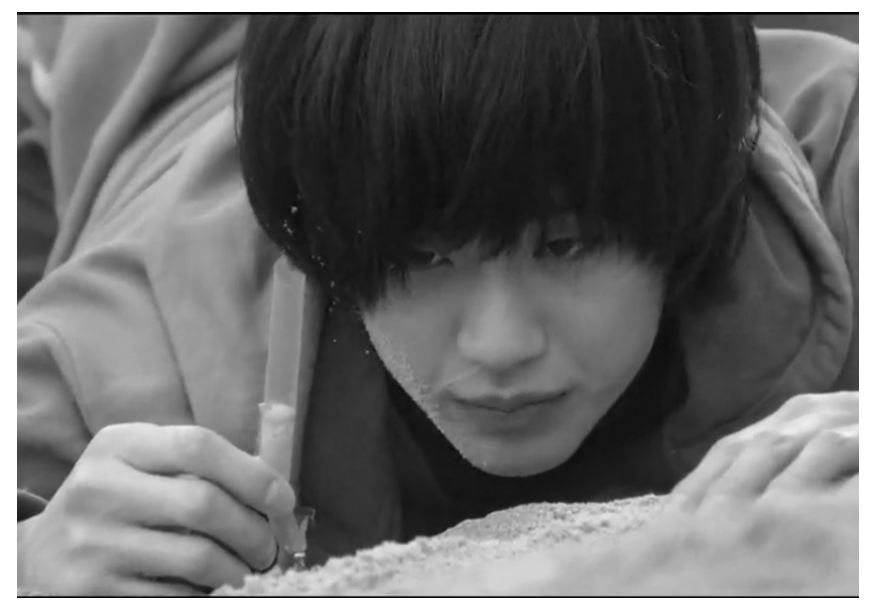

Penyamaran sebagai Bang Dong-Gu

Diterimanya sosok Bang Dong-Gu dalam karena jika tidak demikian, penerimaan masyalingkungan sosial didesa tidak semata-mta karena kebaikan yang dia lakukan. Sosoknya yang merupakan etnis Korea murni juga berperan rakat terhadapnya barangkali akan berbeda, sepertimisalnya penerimaan masyarakat terhadap Young-Kwan di film My Little Hero. Hal ini 
menunjukkan homogenitas etnis yang menjadi dasar dalam memandang sesama manusia.

"South Korean national identity is based on ethnic homogeneity. The population of South Korea in 2011 was 49.78 million, 97.25 per cent of them ethnic Koreans. This single ethnic society facilitated the smooth spread of the nationalistic sentiment among the people. Their strong sense of unity and national pride stem from an identity based on a common bloodline and a shared ancestry." (Seow, 2013:4)

Peryataan diatas serta bukti-bukti dari film turut menegaskan hal ini. Kemudahan dalam berbaur dengan penduduk Korea Selatan dapat dengan mudah dia dapatkan karena adanya rasa persatuan atas dasar kesamaan etnis yang menumbuhkan perasaan kebangsaan.

\section{Won Ryu-Han Sebagai Warga Negara Korea}

\section{Utara}

Di negara asalnya, Korea Utara, dia adalah salah satu pemimpin kelompok dalam satuan pasukan rahasia khusus 5446 dari partai "Red Cliff Flower". Dia telah melalui pelatihan militer selama 9 tahun.
Pasukan 5446 yang dibentuk Kim Jong-Il dan Lee Mu-Hyeok 16 tahun yang lalu. Pasukan ini merupakan orang-orang pilihan yang telah mengalahkan puluhan pasukan berbakat. Mereka dilatih secara brutal, hingga seperti sekumpulan hewan buas. Mereka yang tidak patuh akan menjadi tawanan bodoh. (Secretly Greatly, 00:29:34)

Penggalan teks diatas menunjukkan karakter setiap anggota pasukan rahasia 5446 termasuk Won Ryu-Hwan yang dalam film menarasikan dirinya yang sebenarnya sebagai sosok yang berbeda dengan Bang Dong-Gu,

Won Ryu-Hwan: Aku terlahir seperti anjing
liar. Dibesarkan sebagai monster

(Secretly Greatly, 00:01:19)

Di negaraku aku adalah pejuang revolusi.

Di tempat ini aku adalah mata-mata.

(Secretly Greatly, 00:01:34).

Selain itu, selama dua tahun menyembunyikan identitas di Korea Selatan dan dianggap telah diabaikan oleh partai juga negara, Won RyuHan tetap menjalankan penyamarannya hingga datang perintah lain kepadanya. Namun disisi lain dia telah membaur dengan warga desa lain tempat dia menyamar di Korea Selatan.

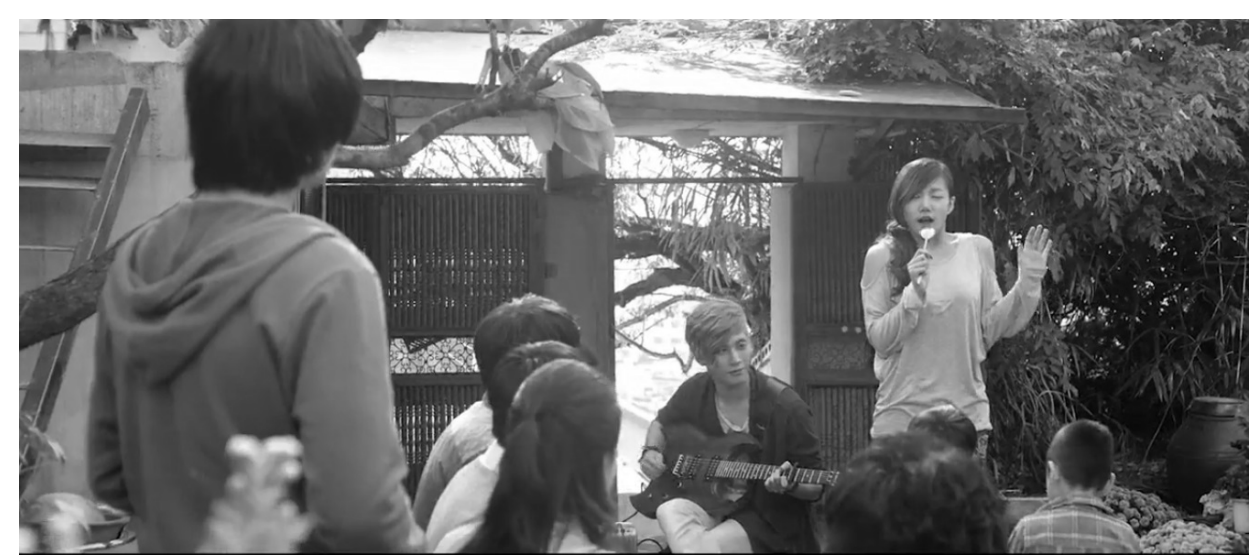

Pada potongan gambar diatas (Secretly Greatly, 00:57:23) terlihat bahwa Won Ryu-Hwan berkumpul bersama warga desa untuk menikmati hidangan dan bernyanyi bersama.

Ketika diturunkan misi kepada seluruh pasukan rahasia untuk bunuh diri atau menunggu dibunuh oleh agen yang akan dikirim ke Korea
Selatan pun dia menyanggupi. Meskipun memang masih ragu untuk segera melaksanakannya mengingat pengorbanannya atas republik dan kebimbangannya atas keselamatan ibunya di Korea Utara. Akhirnya dia memutuskan untuk kembali ke tanah airnya menemui ibunya terlebih dahulu. Namun pada saat yang bersamaan 
instruktur militer Korea Utara telah tiba di Korea Selatan untuk mengeksekusi prajurit rahasia 5446 yang tersisa. Mesipun demikian, Won RyuHwan tetap melanjutkanniatnya dengan berusaha meminimalisir kerusakan yang akan terjadi didesa jika pihak Korea Utara benar-benar datang.

Won Ryu-Hwan: Dalam tubuh kita terdapat pelacak. Komrad instruktur militer selalu mengikuti kita selama ini.

Lee Hae-Rang: Baguslah, kita tidak perlu repot mencarinya.

Won Ryu-Han: Jangan tunggu dia di desa ini. Orang-orang di sini bisa berada dalam bahaya

(Secretly Greatly, 01:23:30)

Percakapan di atas mempertegas bahwa dalam diri Won Ryu-Hwan dan Lee Hae-Rang yang juga pasukan rahasi 5446 telah tumbuh kepedulian atas kelangsungan hidup warga di desa tersebut. Ini terkait dengan nilai-nilai Konfusianisme yang telah berpengaruh sejah masa dinasti Choson (1392) di Korea Selatan. Nilai-nilai tersebutmenekankan pada kemanusiaan, etika moralitas, spiritualitas, kebajikan, harmoni, kepercayaan, kesopanan, keadilan, dan kesetiaan (Baoyun dalam Yim, 2002: 38). Dapat dikatakan bahwa nilai-nilai Korea Selatan sedikit banyak telah diterima oleh Won Ryu-Han.

\section{Kesimpulan}

Melaui media, filmmakers dan negara, sebagai pihak yang berkuasa dapat meluncurkan diskursus tentang identitas nasional yang terkonstruksi dalam media. Dalam film, tidak hanya konsep identitas nasionalyang dapat dibahas dalam kedua film ini, ideologiyang berusaha disebarkan dibalik kedua film ini menarik untuk dianalisis lebih lanjut. Berdasarkan analisis terhadap dua karakter tersebut diketahui bahwa identitas nasional yang ditampilkan dalam film kedua film merepresentasikan kegalauan atas konsep identitas nasional Korea Selatan. Di film My Little Hero ditunjukkan bahwa identitas yang berdasarkan kemurnian darah atau homogenitas etnis sebagai pemersatu dan kebanggan mulai bergeser menjuju identitas bersifat multikultur yang lebih cair. Meskipun demikian, pergeseran itu masih disertai kegalauan akan cita-cita kemurnian etnis yang semata-mata merupakan nostalgia yang disisakan sejak jaman pendudukan Jepang. Dalam film Secretly Greatly, identitas nasional Korea Selatan ditandai dengan kemurnian ras serta pengaplikasian pengaruh nilai-nilai Konfusionisme peninggalan dinasti Choson. Sehingga, seseorang dapat dengan mudah menjadi dan diakui tanpa curiga sebagai seorang Korea Selatan asal berdarah murni, tanpa peduli bahwa orang tersebut berstatus warga negara asing. Teks-teks lain di luar kedua film juga menyatakan bahwa kegalauan ini juga terjadi dalam konteks masyarakat etnis Korea Selatan yang pada kenyataannya sudah tidak homogen lagi. Bukankah globalisasiyang telah berlangsung lama semestinya menjadikan identitas nasional lebih cair? 


\section{DAFTAR PUSTAKA}

Anderson, Benedict. 2001.Imagined Community: Komunitas-Kounitas Terbayang. Yogyakarta: Insist.

Barker, Chris. 2000. Cultural Studies: Teori \& Praktik. Bantul: Kreasi Wacana.

Barker, Chris. 2004. The SAGE Dictionary of Cultural Studies. London, Thousand Oaks, \& New Delhi: Sage Publications.

Connor, Mary E. (ed.). 2009. Asia in Focus: The Koreas. Santa Barbara, Denver, \& Oxford: ABC-CLIO.

Laclau, Ernesto (ed.). 1994. The Making of Political Identities. London \& New York: Verso.

Laclau, Ernesto (ed.). 1994. The Making of Political Identities. London \& New York: Verso.

Lee, Jee Sun E. 2009. Post-unification Korean National Identitity. USKI Working Research Paper Series. Vol. April. Hal. 3-17.

Seow, Jing Yin. 2013. Pride of the People: South Korea and Korean Nationalism. Isis Focus. No.8. Hal 4-8.
Stokes, Jane. 2003. How to do Media and Cultural Studies: Panduan untuk Melaksanakan Penelitian dala Kajian Media dan Budaya. Yogyakarta: Bentang Pustaka.

Sung, Kyung-Kim. 'Renaissance of Korean National Cinema" as a Terrain of Negotiation and Contention between Global and the Local: Analysing two Korean Blockbusters, Shiri (1999) and JSA (2000). Jurnal online diakses 18 Juni 2015, http:// www.essex.ac.uk/sociology/documents/pdf/ graduate_journal/kim.pdf

Turner, Grame. 1988. Film as Social Practice. London \& New York: Routledge.

Vick, Tom. 2009. Cinema as a WIndow on Contemporary Korea. Education About Asia. Vol 14 No. 3. Hal. 37-41.

Yim, Haksoon. 2002. Cultural Identity and Cultural Policy in South Korea. The International Journal of Cultural Policy. Vol 8 No 1. Hal. 37-48. 